\title{
Characterization and complementation of mutants of Methylophilus methylotrophus that have thermolabile forms of proteins involved in $\mathrm{C}_{1}$ metabolism
}

\author{
N. Hutchinson and P. M. Goodwin* \\ School of Cell and Molecular Biology, North East Surrey College of Technology, Reigate Road, Ewell, Epsom, \\ Surrey KT17 3DS, UK
}

(Received 18 August 1992; revised 9 November 1992; accepted 17 November 1992)

\begin{abstract}
Two temperature-sensitive mutants of Methylophilus methylotrophus have been isolated and characterized. The first, NH-4, had a temperature-sensitive defect in methylamine oxidation and was unable to utilize methylamine as sole carbon and nitrogen source at $42^{\circ} \mathrm{C}$. The activities of the methylamine oxidation system and methylamine dehydrogenase in cells grown on methylamine at $30^{\circ} \mathrm{C}$ were much more thermolabile than those of the wild-type. Furthermore, the affinity of the mutant enzyme for methylamine was lower than that of the wild-type enzyme. These results suggest that NH-4 produces a mutant enzyme with an altered conformation which is more susceptible to thermal denaturation than the wild-type enzyme. Surprisingly, this mutant could grow at $42{ }^{\circ} \mathrm{C}$ on media containing methylamine if an alternative carbon or nitrogen source was available. The methylamine oxidation system of whole cells grown under these conditions was not inactivated at $42^{\circ} \mathrm{C}$. The second mutant, NH-7, was unable to grow at the restrictive temperature on media containing either methanol or methylamine as sole carbon source. It contained thermolabile forms of methanol and methylamine dehydrogenases and cytochrome $c_{\mathrm{L}}$. This phenotype could be due to a mutation in a gene essential for the production of mature forms of these periplasmic proteins, which are involved in $\mathrm{C}_{1}$ metabolism. Cosmid pAD833, which has previously been shown to carry genes involved in methanol oxidation (mox genes), complemented both NH-4 and NH-7. Subcloning indicated that the gene which complemented NH-7 was within a $3 \mathrm{kbp}$ region which contained at least two mox genes. This region was near an 8 kbp region containing the gene which complemented mutant NH-4.
\end{abstract}

\section{Introduction}

Methylophilus methylotrophus is able to use methanol or methylated amines as sole carbon source. These compounds are metabolized to formaldehyde, which is then either oxidized to carbon dioxide or assimilated via the ribulose monophosphate pathway (Anthony, 1982). Methylamine can also provide the sole source of nitrogen for growth of this bacterium (Dawson et al., 1990).

Methanol dehydrogenase (EC 1.1.99.8), a periplasmic quinoprotein composed of two large (alpha) and two small (beta) subunits, catalyses the oxidation of methanol; electrons are passed from pyrroloquinoline quinone to a specific electron acceptor, cytochrome $c_{\mathrm{L}}$, and then to cytochrome $c_{\mathrm{H}}$, a typical class I $c$-type cytochrome. In $M$. methylotrophus the terminal electron acceptor may be either cytochrome $a a_{3}$ or cytochrome $c o$,

\footnotetext{
* Author for correspondence. Present address: The Wellcome Trust, 183 Euston Road, London NW1 2BE, UK. Tel. 071611 8888; fax 071 6118545 .
}

depending on the growth conditions (Anthony, 1988). There is evidence from work with the pink-pigmented facultative methylotrophs that at least 20 genes ( $m o x$ genes) are involved specifically in methanol oxidation (reviewed by Goodwin, 1990 a, $b$; Lidstrom, 1990). The genetics of methanol oxidation in $M$. methylotrophus have not been extensively studied but five classes of methanol oxidation (Mox) mutants have been described and genes which complement these mutants are linked (Dawson \& Goodwin 1990).

Methylamine is oxidized by methylamine dehydrogenase (EC 1.4.99.3), another periplasmic protein composed of two large (alpha) and two small (beta) subunits (Haywood et al., 1982), and there is recent evidence that the prosthetic group of this enzyme is tryptophan tryptophylquinone (McIntire et al., 1991). In some methylotrophs electrons are thought to pass from methylamine dehydrogenase to a blue copper protein, amicyanin, and then to cytochrome $c_{\mathrm{H}}$. However, amicyanin has not been detected in $M$. methylotrophus and cytochrome $c_{\mathrm{H}}$ or another $c$-type cytochrome may 
Table 1. Bacterial strains and plasmids

\begin{tabular}{|c|c|c|}
\hline Strain/plasmid & $\begin{array}{c}\text { Relevant } \\
\text { characteristic }\end{array}$ & $\begin{array}{l}\text { Source/ } \\
\text { reference }\end{array}$ \\
\hline \multicolumn{3}{|l|}{ Escherichia coli } \\
\hline S17-1 & $\begin{array}{l}\text { recA thi pro; contains the tra } \\
\text { region of RP4 integrated in the } \\
\text { chromosome }\end{array}$ & Simon et al. (1983) \\
\hline \multicolumn{3}{|l|}{ Methylophilus methylotrophus } \\
\hline G37-5M & $\begin{array}{l}\text { Low-polysaccharide-producing } \\
\text { derivative of NCIB } 10515\end{array}$ & $\begin{array}{l}\text { D. Byrom, ICI } \\
\text { Billingham, UK }\end{array}$ \\
\hline $\mathrm{NH}-4$ & $\begin{array}{l}\text { Temperature-sensitive mutant } \\
\text { unable to grow on methylamine } \\
\text { at } 42^{\circ} \mathrm{C}\end{array}$ & This study \\
\hline $\mathrm{NH}-7$ & $\begin{array}{l}\text { Temperature-sensitive mutant } \\
\text { unable to grow on methanol or } \\
\text { methylamine at } 42^{\circ} \mathrm{C}\end{array}$ & This study \\
\hline \multicolumn{3}{|l|}{ Cosmids } \\
\hline pLA2917 & IncP1 mobilizable; $\mathrm{Tc}^{\mathrm{r}} \mathrm{Km}^{\mathrm{r}}$ & $\begin{array}{l}\text { Allen \& Hanson } \\
(1985)\end{array}$ \\
\hline $\begin{array}{l}\text { Sau3A clone bank of } M \\
\text { methylotrophus DNA in } \\
\text { pLA2917 }\end{array}$ & Host $E$. coli $\mathrm{S} 17-1$ & Lyon et al. (1988) \\
\hline $\begin{array}{l}\text { pAD428, pAD833, pAD1149, } \\
\text { pAD848, pAD1742, pAD833-1, } \\
\text { pAD833-2, pAD1149-1 }\end{array}$ & $\begin{array}{l}\text { Cosmids isolated from the clone } \\
\text { bank which complemented } \\
\text { NH-4 }\end{array}$ & $\begin{array}{l}\text { Dawson \& Goodwin } \\
\text { (1990) }\end{array}$ \\
\hline
\end{tabular}

accept electrons directly from methylamine dehydrogenase (Anthony, 1992). The genetics of methylamine oxidation have not been studied in M. methylotrophus, but it has recently been shown that in Methylobacterium extorquens AM1 the structural genes encoding the two subunits of methylamine dehydrogenase are linked to the structural gene encoding amicyanin (Chistoserdov et al., 1991). In Thiobacillus versutus the genes encoding amicyanin and the beta subunit of methylamine dehydrogenase are also linked (Ubbink et al., 1991).

Studies of mutants defective in the metabolism of $\mathrm{C}_{1}$ compounds have enhanced our understanding of the biochemistry of both the oxidation and assimilation of methanol and methylamine (reviewed by Anthony, 1982; Goodwin, 1990 $a, b$; Lidstrom, 1990). In this paper we describe the properties of two novel mutants of Methylophilus methylotrophus which have temperature-sensitive defects in the oxidation of $\mathrm{C}_{1}$ compounds.

\section{Methods}

Growth of bacteria. The bacterial strains and cosmids used are shown in Table 1. M. methylotrophus was grown on seed 2 medium as described by Southgate \& Goodwin (1989) and Dawson \& Goodwin (1990) and supplemented as appropriate with methanol $(0 \cdot 4 \%, v / v)$ or methylamine hydrochloride $(0.4 \%, \mathrm{w} / \mathrm{v})$.

Isolation of mutants. Mutagenesis with $N$-methyl- $N^{\prime}$-nitro- $N$-nitrosoguanidine was done as described by Dawson \& Goodwin (1990). Mutagenized cells were incubated overnight at $30^{\circ} \mathrm{C}$ in medium containing methanol as sole carbon source to express the mutations. Then the bacteria were washed, resuspended in fresh methanol medium and incubated at $42{ }^{\circ} \mathrm{C}$ for $3 \mathrm{~h}$. Ampicillin and cycloserine were then added (each to a final concentration of $0.02 \mathrm{mg} \mathrm{ml}^{-1}$ ) and the culture incubated overnight at $42^{\circ} \mathrm{C}$. The surviving cells were plated onto methanol medium and incubated at $30^{\circ} \mathrm{C}$. Single colonies were picked off and tested for the ability to grow on (i) methanol and (ii) methylamine at $42{ }^{\circ} \mathrm{C}$.

Whole-cell oxidation studies. The abilities of whole cells to oxidize methanol and methylamine were determined as described by Dawson et al. (1990). For each strain the assays were done using at least two concentrations of cells and each experiment was repeated with three different batches of cells. Results were reproducible to within $\pm 5 \%$.

Preparation of cell extracts and enzyme assays. Cell extracts were prepared as described by Southgate \& Goodwin (1989). Methanol dehydrogenase was assayed polarographically by the method of Dunstan et al. (1972), as modified by Tatra \& Goodwin (1985) and Southgate \& Goodwin (1989). Methylamine dehydrogenase was also assayed polarographically, using a method based on that of Eady \& Large (1968) as modified by Dawson et al. (1990). In both assays phenazine ethosulphate was the electron acceptor. Each enzyme assay was repeated using at least two concentrations of extract to check that the enzyme was limiting; each experiment was repeated with three different batches of cells. Results were reproducible to within $\pm 5 \%$.

Purification of methylamine dehydrogenase. Methylamine dehydrogenase was purified from the wild-type and mutant $\mathrm{NH}-4$ using the method of Haywood et al. (1982); both strains were grown on methylamine. The second stage of the procedure involved heat treatment of crude extracts at $75^{\circ} \mathrm{C}$ for $20 \mathrm{~min}$. Although the mutant enzyme was thermolabile, the loss of activity on heat treatment was partially reversible; on cooling to $30^{\circ} \mathrm{C}, 40 \%$ of the activity was recovered, compared with a recovery of $81 \%$ of the wild-type enzyme. The purified enzymes from both strains were homogeneous as judged by SDS-PAGE. The wild-type enzyme was purified 75 -fold, with a $9.8 \%$ yield, and the mutant enzyme 14 -fold, with a $1.5 \%$ yield.

Effect of chymotrypsin on methylamine dehydrogenase activity. Crude extracts of the wild-type and mutant NH-4 grown on methylamine were treated as described by Nakano \& Kimura (1990). The initial 
Table 2. Oxidation of methylamine by whole cells and specific activities of methylamine dehydrogenase in wild-type and mutant strains

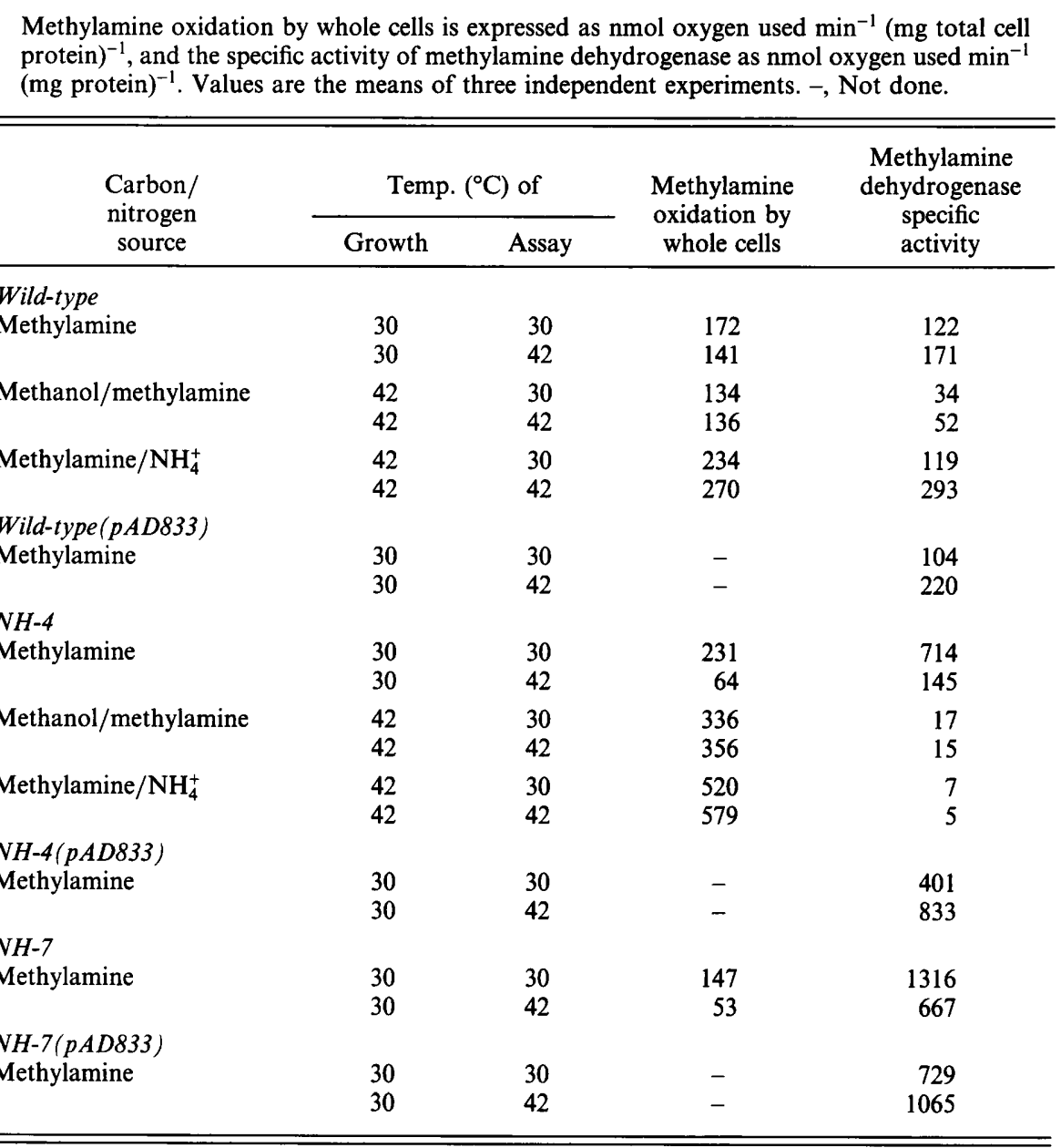

specific activities of the methylamine dehydrogenases in the wild-type and mutant extracts were 157 and $500 \mathrm{nmol}$ oxygen used $\mathrm{min}^{-1}$ (mg protein $)^{-1}$, respectively; the protein concentrations of the mutant and wild-type extracts used for the digestions were the same.

SDS-PAGE and haem staining. This was done as described by Dawson \& Goodwin (1990). Gels were stained with Coomassie blue.

Bacterial matings and DNA manipulations. These were done as described by Dawson \& Goodwin (1990).

\section{Results}

\section{Isolation and growth properties of mutants}

More than 800 temperature-sensitive mutants were isolated after mutagenesis with $N$-methyl- $N^{\prime}$-nitro- $N$ nitrosoguanidine and ampicillin/cycloserine enrichment. Three phenotypes were observed at the restrictive temperature $\left(42^{\circ} \mathrm{C}\right):(a)$ mutants unable to use methanol as sole carbon source $(1 \%$ of the total $) ;(b)$ mutants unable to grow on medium containing either methanol or methylamine as carbon source $(27 \%$ of the total; $44 \%$ of these were auxotrophs): (c) mutants unable to use methylamine as sole carbon and nitrogen source ( $72 \%$ of the total). This last group was unexpected since the conditions used for expression and enrichment should not have selected for this phenotype.

Many of these temperature-sensitive mutants were unstable but two, designated NH-4 and NH-7, which reverted at a frequency of about $10^{-9}$, were selected for further study. NH-7 grew slowly on methanol medium at $30^{\circ} \mathrm{C}$ and was unable to use either methanol or methylamine as sole carbon source at $42^{\circ} \mathrm{C}$, even in the presence of growth factors. During harvesting of the mutant cells we noticed that they were more susceptible to lysis than those of the wild-type strain; centrifugation of a wild-type culture for $10 \mathrm{~min}$ at 800 r.p.m. had little effect on the number of viable cells whilst the same treatment of an equivalent culture of mutant NH-7 caused a 1000 -fold drop in viability.

NH-4 had unexpected growth properties - it was unable to grow at $42^{\circ} \mathrm{C}$ on medium containing methylamine as sole carbon and nitrogen source, but could 
Table 3. $K_{\mathrm{m}}$ and $V_{\max }$ values of methylamine dehydrogenase from wild-type and mutant strains

$K_{\mathrm{m}}$ is expressed in $\mu \mathrm{M}$ and $V_{\max }$ in $\mathrm{nmol} \min ^{-1}$ (mg protein) ${ }^{-1}$. Extracts and purified enzymes were from cells grown on methylamine at $30^{\circ} \mathrm{C}$. - , Not done.

\begin{tabular}{|c|c|c|c|c|c|c|c|}
\hline \multirow[b]{2}{*}{ Substrate } & \multirow{2}{*}{$\begin{array}{c}\text { Assay } \\
\text { temp. } \\
\left({ }^{\circ} \mathrm{C}\right)\end{array}$} & \multicolumn{2}{|c|}{ Wild-type } & \multicolumn{2}{|c|}{ Mutant NH-4 } & \multicolumn{2}{|c|}{ Mutant NH-7 } \\
\hline & & $K_{\mathrm{m}}$ & $V_{\max }$ & $K_{\mathrm{m}}$ & $V_{\max }$ & $K_{\mathrm{m}}$ & $V_{\max }$ \\
\hline $\begin{array}{l}\text { Crude extracts } \\
\text { Methylamine }\end{array}$ & $\begin{array}{l}30 \\
42\end{array}$ & $\begin{array}{l}51 \\
73\end{array}$ & $\begin{array}{l}254 \\
302\end{array}$ & $\begin{array}{l}211 \\
150\end{array}$ & $\begin{array}{l}604 \\
267\end{array}$ & $\begin{array}{c}875 \\
-\end{array}$ & $\begin{array}{c}1995 \\
-\end{array}$ \\
\hline Phenazine ethosulphate & $\begin{array}{l}30 \\
42\end{array}$ & $\begin{array}{l}52 \\
98\end{array}$ & $\begin{array}{l}705 \\
112\end{array}$ & $\begin{array}{r}151 \\
67\end{array}$ & $\begin{array}{r}290 \\
72\end{array}$ & $\begin{array}{l}- \\
-\end{array}$ & $\begin{array}{l}- \\
-\end{array}$ \\
\hline $\begin{array}{l}\text { Purified enzyme } \\
\text { Methylamine }\end{array}$ & $\begin{array}{l}30 \\
42\end{array}$ & $\begin{array}{l}49 \\
71\end{array}$ & $\begin{array}{r}8660 \\
17470\end{array}$ & $\begin{array}{l}203 \\
160\end{array}$ & $\begin{array}{l}8145 \\
1740\end{array}$ & $\begin{array}{l}- \\
-\end{array}$ & - \\
\hline
\end{tabular}

grow at this temperature when methylamine was the sole carbon source and $\mathrm{NH}_{4}^{+}$was available as an alternative nitrogen source. It could also grow at $42^{\circ} \mathrm{C}$ when methylamine provided the sole nitrogen source and methanol was present as an alternative carbon source.

\section{Oxidation of methylamine}

Strains were grown at $30^{\circ} \mathrm{C}$ on medium containing methylamine as sole carbon and nitrogen source and their abilities to oxidize methylamine at $30^{\circ} \mathrm{C}$ and $42{ }^{\circ} \mathrm{C}$ were compared (Table 2). At $30^{\circ} \mathrm{C}$ methylamine was oxidized at a similar rate by whole cells of the wild-type and mutant strains. At $42^{\circ} \mathrm{C}$ the rate at which the wildtype oxidized methylamine was slightly reduced, but in the mutant strains it was decreased three- to fourfold. The specific activity of methylamine dehydrogenase assayed at $30^{\circ} \mathrm{C}$ in extracts of the mutants was severalfold higher than in the wild-type, but assaying at $42{ }^{\circ} \mathrm{C}$ demonstrated that, in contrast to the wild-type enzyme, the mutant enzymes were thermolabile.

The rates of oxidation of methylamine by the wildtype and mutant NH-4 which had been grown at $42^{\circ} \mathrm{C}$ on medium containing either methanol plus methylamine or methylamine plus $\mathrm{NH}_{4}^{+}$were also compared (Table 2). The methylamine oxidation activity in whole cells of the mutant grown under these conditions was greater than that of wild-type cells and, in contrast to the methylamine-grown mutant cells, the assay temperature had little effect on the oxidation rate. However, the specific activities of methylamine dehydrogenase assayed at $30^{\circ} \mathrm{C}$ in extracts of the mutant grown on methanol plus methylamine or on methylamine plus $\mathrm{NH}_{4}^{+}$were respectively twofold and 17-fold lower than in the wildtype extracts grown under the same conditions. Increasing the assay temperature to $42^{\circ} \mathrm{C}$ had relatively little effect on activity of the mutant enzyme.

\section{Apparent $K_{\mathrm{m}}$ for methylamine}

The apparent $K_{\mathrm{m}}$ values of the wild-type and mutant methylamine dehydrogenases were estimated at both $30^{\circ} \mathrm{C}$ and $42^{\circ} \mathrm{C}$ using extracts of cells grown at $30^{\circ} \mathrm{C}$ on methylamine as sole carbon and nitrogen source (Table 3 ). The apparent affinity of the wild-type enzyme for methylamine was slightly lower at $42{ }^{\circ} \mathrm{C}$ than at $30^{\circ} \mathrm{C}$. In contrast, the apparent $K_{\mathrm{m}}$ in extracts of mutant $\mathrm{NH}-4$ was four times greater than that of the wild-type at $30^{\circ} \mathrm{C}$, but only twice that of the wild-type enzyme at $42{ }^{\circ} \mathrm{C}$. The $V_{\max }$ of the mutant enzyme at $30^{\circ} \mathrm{C}$ was almost threefold greater than that of the wild-type, but was slightly less than the wild-type at $42{ }^{\circ} \mathrm{C}$.

The methylamine dehydrogenases from the wild-type and mutant NH-4 were also purified as described in Methods. This involved affinity chromatography through an aminopentylagarose column; $65 \%$ of the mutant enzyme eluted with the void volume, whereas most of the wild-type enzyme activity was retained, confirming that the mutant enzyme had an altered substrate affinity. The $K_{\mathrm{m}}$ values of the purified enzymes were the same as those determined in the crude extracts. The apparent $K_{\mathrm{m}}$ and $V_{\max }$ values measured in the presence of different concentrations of the artificial electron acceptor phenazine ethosulphate were also altered in the mutant extracts.

The apparent $K_{\mathrm{m}}$ for methylamine and the $V_{\max }$ of the methylamine dehydrogenase of mutant $\mathrm{NH}-7$ were much greater than the values determined for the wild-type enzyme (Table 3 ).

\section{Effect of chymotrypsin on methylamine dehydrogenase activity}

The effect of limited proteolysis by chymotrypsin on the activities of the methylamine dehydrogenases of the wildtype and mutant NH-4 was investigated. Sixty-eight 


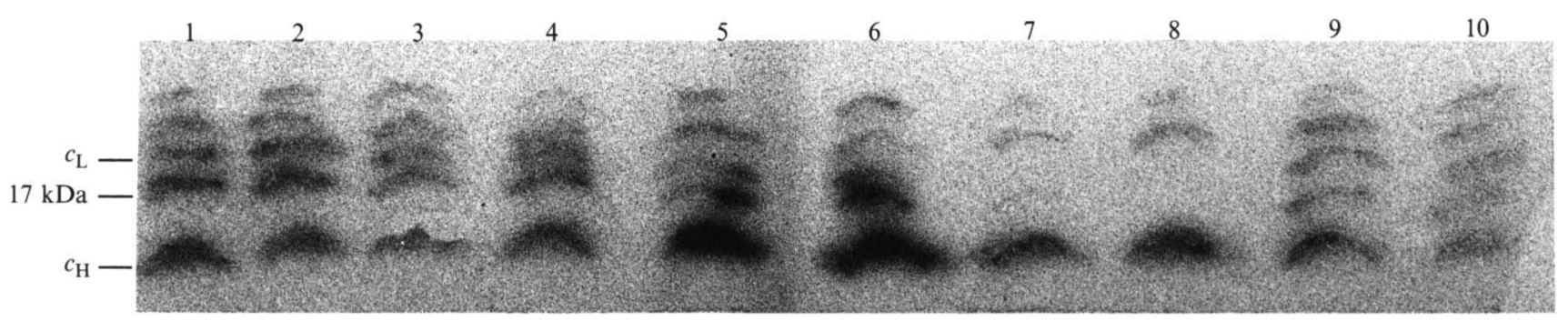

Fig. 1. SDS-PAGE showing haem-staining proteins of wild-type and mutant strains of $M$. methylotrophus. Strains were grown on methylamine at $30^{\circ} \mathrm{C}$ and then incubated at $42^{\circ} \mathrm{C}$ for $6 \mathrm{~h}$ unless stated. Lanes: 1, wild-type(pAD833-2); 2, wild-type(pAD833-1); 3, wild-type; 4, NH-4(pAD833-2); 5, NH-4(pAD833-1); 6, NH-4; 7, NH-7; 8, NH-7(pAD833-2); 9, NH-7(pAD833-1); 10, wild-type (not incubated at $\left.42{ }^{\circ} \mathrm{C}\right)$.

Table 4. Oxidation of methanol by whole cells and specific activities of methanol dehydrogenase in wildtype and mutant strains grown at $30^{\circ} \mathrm{C}$ on methylamine as sole carbon and nitrogen source

Methanol oxidation by whole cells is expressed as nmol oxygen used $\mathrm{min}^{-1}$ (mg total cell protein) $)^{-1}$ and the specific activity of methanol dehydrogenase as nmol oxygen used $\min ^{-1}$ (mg protein $)^{-1}$. Values are the means of three independent experiments. ND, Not detectable; -, not done.

\begin{tabular}{lccc}
\hline \hline \multicolumn{1}{c}{ Strain } & $\begin{array}{c}\text { Assay } \\
\text { temp. } \\
\left({ }^{\circ} \mathrm{C}\right)\end{array}$ & $\begin{array}{c}\text { Methanol } \\
\text { oxidation by } \\
\text { whole cells }\end{array}$ & $\begin{array}{c}\text { Methanol } \\
\text { dehydrogenase } \\
\text { specific } \\
\text { activity }\end{array}$ \\
\hline Wild-type & 30 & 276 & 124 \\
Wild-type(pAD833) & 42 & 181 & 167 \\
& 30 & - & 118 \\
NH-4 & 42 & - & 170 \\
& 30 & 333 & 116 \\
NH-4(pAD833) & 42 & 257 & 156 \\
& 30 & - & 110 \\
NH-7 & 42 & - & 158 \\
& 30 & 97 & 12 \\
NH-7(pAD833) & 42 & 14 & ND \\
& 30 & - & 120 \\
\hline \hline
\end{tabular}

percent of the activity of the methylamine dehydrogenase of mutant NH-4 was lost during a $2 \mathrm{~h}$ incubation with chymotrypsin, compared with a loss of only $39 \%$ of the wild-type activity. The differences in the susceptibilities of the two enzymes to limited proteolysis is a further indication that they have different conformations.

\section{Methanol oxidation}

The abilities of methylamine-grown wild-type and mutant strains to oxidize methanol were compared (Table 4). Whole cells of the wild-type and $\mathrm{NH}-4$ oxidized methanol at similar rates at $30^{\circ} \mathrm{C}$ and the activities were reduced somewhat at $42^{\circ} \mathrm{C}$. In contrast, the specific activity of methanol dehydrogenase in extracts of these strains was greater at $42{ }^{\circ} \mathrm{C}$ than at $30^{\circ} \mathrm{C}$. Whole cells of mutant NH-7 oxidized methanol at only $35 \%$ of the wild-type rate at $30^{\circ} \mathrm{C}$ and this activity was decreased about sevenfold at $42^{\circ} \mathrm{C}$. Methanol dehydrogenase activity in this mutant was also low compared with that of the wild-type and was thermolabile.

\section{Protein and cytochrome profiles of mutants $\mathrm{NH}-4$ and $\mathrm{NH}-7$}

The protein profiles of wild-type and mutant strains grown on methylamine were compared using SDSPAGE (data not shown). A large polypeptide $(>90 \mathrm{kDa})$, of unknown identity, was present in the wild-type but not in either of the mutants. Apart from this, there was no obvious difference between the strains. However, when SDS-PAGE gels of the wild-type and mutant strains were stained for haem under conditions in which only $c$-type cytochromes are observed, differences were evident (Fig. 1). Five haem-staining bands were present in the wild-type, confirming the results of Dawson \& Goodwin (1990). These included cytochromes $c_{\mathrm{H}}, c_{\mathrm{L}}$ and a $17 \mathrm{kDa}$ haem-staining band which consists of cytochrome $c_{\mathrm{L}}$ and/or cytochrome $c_{\mathrm{LM}}$ (Dawson \& Goodwin, 1990). Cytochrome $c_{\mathrm{LM}}$ was first described by Cross \& Anthony (1980) as a minor $c$-type cytochrome present in methanol-grown $M$. methylotrophus, but its significance in methylamine-grown cells is unclear. Incubation of cell extracts of the wild-type and mutant $\mathrm{NH}-4$ at $42^{\circ} \mathrm{C}$ for $6 \mathrm{~h}$ had no effect on the cytochrome profile, but when extracts of mutant $\mathrm{NH}-7$ were subjected to the same treatment, cytochrome $c_{\mathrm{L}}$ and the $17 \mathrm{kDa}$ haem-staining band were no longer detectable.

\section{Complementation of mutants $\mathrm{NH}-4$ and $\mathrm{NH}-7$}

Five cosmids from a Sau3A gene library of $M$. methylotrophus DNA which had been previously shown to complement some methanol oxidation mutants of $M$. methylotrophus (Dawson \& Goodwin, 1990) also comple- 


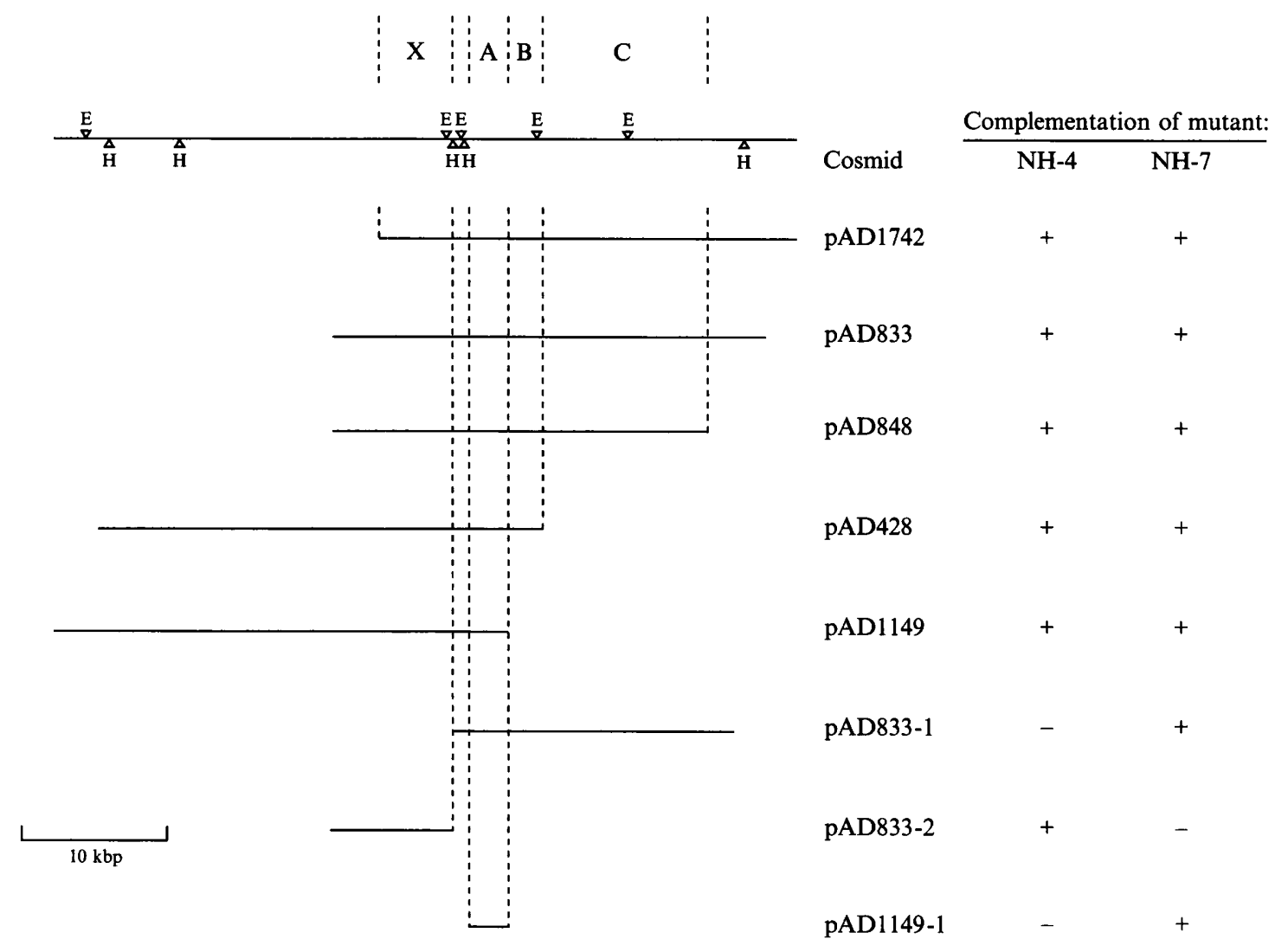

Fig. 2. Restriction maps of cosmids which complemented mutants NH-4 and NH-7. Region A contains genes which complement mutant NH-7 and two classes of Mox mutants; regions B and C contain genes which complement other Mox mutants: region X contains a gene which complements mutant NH-4. E, EcoRI; H, HindIII.

mented NH-4 and NH-7. The complemented mutants had wild-type growth properties at the restrictive temperature and their methylamine and methanol dehydrogenases were not inactivated at $42^{\circ} \mathrm{C}$ (Tables 2 and 4). Furthermore, cytochrome $c_{\mathrm{L}}$ was stable in strains of NH-7 carrying complementing cosmids under conditions in which the cytochrome in the parent strain was denatured (Fig. 1).

Two subclones were derived from cosmid pAD833; one (pAD833-1) complemented NH-7 and the other (pAD833-2) complemented NH-4. Consideration of the restriction maps of the cosmids indicated that the gene complementing mutant NH-4 lay within an $8 \mathrm{kbp}$ region (region X, Fig. 2) close to the cluster of five mox genes. Mutant NH-7 was complemented by a gene located within the mox gene cluster, in a $3 \mathrm{kbp}$ region previously shown to complement two classes of Mox mutants of $M$. methylotrophus (region A, Fig. 2).

\section{Discussion}

Many mutants of methylotrophic bacteria have been described previously (reviewed by Anthony, 1982;
Goodwin $1990 a, b$; Lidstrom 1990), but none resemble NH-4 or NH-7. Mutant NH-7 was unable to grow on methanol or methylamine at the restrictive temperature. It contained thermolabile forms of at least three periplasmic proteins involved in $\mathrm{C}_{1}$ oxidation (methanol and methylamine dehydrogenases and cytochrome $c_{\mathrm{L}}$ ), as well as the $17 \mathrm{kDa}$ haem-staining band which may consist of a degraded form of cytochrome $c_{\mathrm{L}}$ and/or a minor cytochrome $\left(c_{\mathrm{LM}}\right)$ of unknown function. Furthermore, the apparent $K_{\mathrm{m}}$ of the mutant methylamine dehydrogenase for methylamine was more than 10-fold greater than that of the wild-type enzyme, suggesting differences in the conformations of two enzymes. Mutant NH-7 was more susceptible to lysis than the wild-type and this may be due to the presence of abnormal periplasmic proteins which alter the structure of the cell envelope, rendering the cell more fragile than normal. However, not all periplasmic proteins were affected by the mutation since cytochrome $c_{\mathrm{H}}$ (which is also involved in $\mathrm{C}_{1}$ oxidation) was not apparently degraded under conditions which caused complete loss of cytochrome $c_{\mathrm{L}}$. The slow rate of growth of this mutant on methanol at the permissive temperature is presumably due to the fact 
that the methanol oxidation system was much less active at $30^{\circ} \mathrm{C}$ than in the wild-type.

Periplasmic proteins are synthesized as precursors containing $\mathrm{N}$-terminal signal sequences, and must be transported across the inner membrane, presumably with the aid of one or more molecular chaperones. It is possible that $\mathrm{NH}-7$ is mutated in a chaperone required for the transport of precursors of the dehydrogenases and cytochrome $c_{\mathrm{L}}$ (but not cytochrome $c_{\mathrm{H}}$ ), resulting in their misfolding and instability. Alternatively, this mutant may be defective in a factor required for the processing and/or assembly of these three proteins, such that unstable forms are made.

Mutant NH-4 was unable to use methylamine as sole carbon and nitrogen source at $42^{\circ} \mathrm{C}$ and the methylamine oxidation and methylamine dehydrogenase activities in cells grown on methylamine at $30^{\circ} \mathrm{C}$ were inactivated at $42^{\circ} \mathrm{C}$. Furthermore, the apparent $K_{\mathrm{m}}$ for methylamine of the mutant dehydrogenase in crude extracts and in the purified form was fourfold greater than that of the wild-type enzyme, and the mutant enzyme was more susceptible to chymotrypsin degradation. These observations are consistent with the hypothesis that the mutation caused production of an enzyme with an altered conformation which was rapidly inactivated at $42^{\circ} \mathrm{C}$. Such a mutation could be in one of the structural genes at a residue with a key role in folding, or in a gene required specifically for the correct folding and/or assembly of methylamine dehydrogenase.

It is curious that mutant $\mathrm{NH}-4$ could grow at $42^{\circ} \mathrm{C}$ on methylamine plus $\mathrm{NH}_{4}^{+}$and on methylamine plus methanol; cells grown on these substrates oxidized methylamine at a greater rate than did wild-type cells and the methylamine oxidation system of these mutant cells was not thermolabile. The activity of methylamine dehydrogenase in extracts of such cells was low compared with that of the wild-type but, in contrast with the enzyme from methylamine-grown mutant cells, it had similar activities at $30^{\circ} \mathrm{C}$ and $42^{\circ} \mathrm{C}$. This is consistent with our observations (Hutchinson \& Goodwin, 1993) that the in vitro stability of methylamine dehydrogenase varies with the growth conditions and that the enzyme from cells grown on methylamine as sole carbon and nitrogen source is more susceptible to heat denaturation than that from cells grown on methylamine in the presence of an alternative carbon or nitrogen source. Other work has shown that it is unlikely that methylamine dehydrogenase catalyses the rate-limiting step in methylamine oxidation (Dawson et al., 1990; Hutchinson \& Goodwin, 1993). However, further work is required to ascertain whether the activity of methylamine dehydrogenase in mutant NH-4 grown at $42^{\circ} \mathrm{C}$ on methylamine in the presence of an alternative carbon or nitrogen source is sufficient to account for the high rate at which whole cells oxidized methylamine. If it cannot, this would imply that there is another enzyme involved in methylamine oxidation in cells grown under these conditions.

The specific activity of methylamine dehydrogenase in both mutants grown on methylamine was high compared with the wild-type. Further work is required to determine if this is merely a consequence of the increased $V_{\max }$ values of the mutant enzymes, or whether the regulation of methylamine dehydrogenase is abnormal in the mutants.

Mutant NH-4 was complemented by an $8 \mathrm{kbp}$ region of the $M$. methylotrophus chromosome. This may contain the gene defective in this mutant or it may encode one or more proteins which can suppress the effect of the original mutation by preventing denaturation of the enzyme and/or promoting its renaturation. The region which complemented NH-4 is close to a $3 \mathrm{kbp}$ piece of M. methylotrophus DNA (region A in Fig. 2) which complemented mutant NH-7 and at least two classes of Mox mutants. One class consists of temperature-sensitive mutants which are defective in the oxidation of methanol and do not synthesize the alpha subunit of methanol dehydrogenase when grown at the restrictive temperature. The other class comprises a mutant unable to produce either methanol dehydrogenase or its primary electron acceptor, cytochrome $c_{\mathrm{L}}$ (Dawson \& Goodwin, 1990). Clearly it will be important to define this region of the $M$. methylotrophus chromosome in more detail and to determine if it contains the gene which is defective in mutant NH-7 (and is involved in the production of methanol and methylamine dehydrogenases and cytochrome $c_{\mathrm{L}}$ ) or if it encodes a suppressor of the mutation in NH-7.

\section{References}

Allen, L. N. \& Hanson, R. S. (1985). Construction of broad host range cosmid cloning vectors: identification of genes necessary for growth of Methylobacterium organophilum on methanol. Journal of Bacteriology 161, 955-962.

ANTHONY, C. (1982). The Biochemistry of Methylotrophs. London: Academic Press.

ANTHONY, C. (1988). Quinoproteins and energy transduction. In Bacterial Energy Transduction, pp. 293-316. Edited by C. Anthony. London: Academic Press.

ANTHONY, C. (1992). The $c$-type cytochromes of methylotrophic bacteria. Biochimica et Biophysica Acta 1099, 1-15.

Chistoserdov, A., Tsygankov, Y. D. \& Lidstrom, M. E. (1991). Genetic organisation of methylamine utilization genes from Methylobacterium extorquens AM1. Journal of Bacteriology 173, 5901-5908.

Cross, A. R. \& AnTHONy, C. (1980). The purification and properties of the soluble cytochromes $c$ of the obligate methylotroph Methylophilus methylotrophus. Biochemical Journal 192, 421-427.

DAwson, A. \& GoodwIN, P. M. (1990). Investigation of mutants of Methylophilus methylotrophus which are defective in methanol oxidation. Journal of General Microbiology 136, 1373-1380.

Dawson, A., SouthGate, G. \& Goodwin, P. M. (1990). Regulation of methanol and methylamine dehydrogenases in Methylophilus methylotrophus. FEMS Microbiology Letters 68, 93-96. 
Dunstan, P. M., Anthony, C. \& Drabble, W. T. (1972). Microbial metabolism of $C_{1}$ and $C_{2}$ compounds: the involvement of glycollate in the metabolism of ethanol and of acetate by Pseudmonas AM1. Biochemical Journal 128, 99-106.

EADY, R. R. \& LARGE, P. J. (1968). Purification and properties of an amine dehydrogenase from Pseudomonas AM1 and its role in growth on methylamine. Biochemical Journal 106, 245-255.

GoodwIN, P. M. (1990a). The biochemistry and genetics of C-1 metabolism in the pink pigmented facultative methylotrophs. In Autotrophic Microbiology and One-carbon Metabolism, pp. 143-162. Edited by G. A. Codd, L. Dijkhuizen \& R. Tabita. Dordrecht: Kluwer Academic Publishers.

Goodwin, P. M. (1990b). Genetic organisation of methanol oxidation in methylotrophs. In Proceedings of the 6th International Symposium on Genetics of Industrial Microorganisms, pp. 621-630. Edited by H. Heslot, J. Davies, J. Florent, L. Bobichon, G. Durand \& L. Penasse. Strasbourg: Société Française de Microbiologie.

HaYwoOD, G. W., JanschKe, N. S., LARGe, P. J. \& Wallis, J. M. (1982). Properties and subunit structure of methylamine dehydrogenase from Thiobacillus A2 and Methylophilus methylotrophus. FEMS Microbiology Letters 15, 79-82.

Hutchinson, N. \& Goodwin, P. M. (1993). Investigation of thermolabile variants of the methanol and methylamine dehydrogenases of Methylophilus methylotrophus and the effect of an $11.5 \mathrm{kbp}$ region of the chromosome on the stability of these enzymes. Journal of General Microbiology 139, 547-555.

LidsTROM, M. E. (1990). Genetics of carbon metabolism in methylotrophic bacteria. FEMS Microbiology Reviews 87, 431-436.
Lyon, B. R, Kearney, P. P., Sinclair, M. I. \& Holloway, B. W. (1988). Comparative complementation mapping of Methylophilus spp. using cosmid gene libraries and prime plasmids. Journal of General Microbiology 134, 123-132.

McIntire, W. S., Wemmer, D. E., Chistoserdov, A. \& Lidstrom, M. E. (1991). A new cofactor in a prokaryotic enzyme: tryptophan tryptophylquinone as the redox prosthetic group in methylamine dehydrogenase. Science 252, 817-824.

NaKano, Y. \& KimuRA, K. (1990). Temperature-sensitive mutant of Bacillus subtilis glutamine synthase obtained by random mutation. Journal of Biochemistry 108, 116-121.

Simon, R., Priefer, U. \& Puhler, A. (1983). A broad host range mobilization system for in vivo genetic engineering: transposon mutagenesis in Gram negative bacteria. Biotechnology 1, 784-791.

SouthGate, G. \& GoodWIN, P. M. (1989). The regulation of exopolysaccharide production and of enzymes involved in $\mathrm{C}_{1}$ metabolism in Methylophilus methylotrophus. Journal of General Microbiology 135, 2859-2867.

TAtra, P. K. \& Goodwin, P. M. (1985). Mapping of some genes involved in $\mathrm{C}_{1}$ metabolism in the facultative methylotroph Methylobacterium sp. strain AM1 (Pseudomonas AM1). Archives of Microbiology 143, 169-177.

Ubbink, M., van Kleef, M. A. G., Kleinjan, D.-J., Hoitink, C. W. G., Huitema, F., Beintema, J. J., Duine, J. A. \& Canters, G. W. (1991). Cloning, sequencing and expression studies of the genes encoding amicyanin and the beta subunit of methylamine dehydrogenase from Thiobacillus versutus. European Journal of Biochemistry 202, 1003-1012. 